\title{
A TEN YEARS HAIL CLIMATOLOGY BASED ON ESWD HAIL REPORTS IN ROMANIA, 2007-2016
}

\author{
Vasilică ISTRATE ${ }^{1,2}$, Radu-Vlad DOBRI ${ }^{1,2}$, Florentina BARC $\breve{A C I A N U}^{1}$, \\ Răzvan Alin CIOBANU ${ }^{2}$, Liviu APOSTOL ${ }^{1}$
}

DOI: 10.21163/GT_2017.122.10

\begin{abstract}
:
The present work analyse dstatistically representative number of severe convective events reported for ESWD (European Severe Weather Database) which caused hail in Romania during 2007-2016. We used only data from QC1 (report confirmed) level of credibility. QC1 are reports confirmed by reliable sources by ESSL (European Severe Storm Laboratory) Quality Control Division and National Meteorological Institutes. The development of social media and an increasing number of people interested in severe weather in the recent years significantly raised the number of reports, too (often accompanied by a photograph of the event). This database does not include all of the hail reports, but it is the best existing source for the Romanian territory. For the 2007-2016 period, 470 events with QC1 credibility were reported for ESWD. A spatial-temporal analysis of ESWD reports has been carried out. During the ten years, a high density of reporting has been observed in north-east, south-east and north-western Romania.. This is a consequence of the number of volunteers reporting extreme weather events and local climatic conditions. A greater number of hail days can be noted in 2008, 2009 and 2010, a decline in 2011 and 2012, and during 2013-2016, 10 to 12 of hail days per year were actually recorded.
\end{abstract}

Key-words: Hailstorm, ESWD, Hail reports density, Romania.

\section{INTRODUCTION}

The amount of damage caused by hailstorms grows even more in the agricultural sector, when considering the latest increase of crops in economic terms. The first step into hail suppression is to know its spatial and temporal features. The purpose of this study is the improvement of the hail forecast for the Romanian territory, which would help the nowcasting warnings, but also for the benefit of the National System of Hail Suppression that is in full development.

In Europe, hail climatology or other studies related to hail have been assignedto most of the countries. Among these, we mention studies that focus on South-eastern Europe and neighbouring countries of Romania. A fully-consistent study of hailstorms and hail affected areas was made in 2016 (Punge \& Kunz, 2016). The European Severe Storms Laboratory (ESSL) detailed a preliminary climatology based on big-sized hailstones $(>20 \mathrm{~mm})$ in Europe during 2000-2007 (Hand \& Cappelluti, 2011).

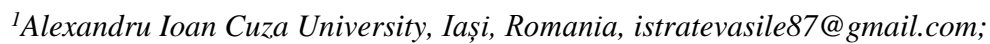
dobri.vlad@yahoo.com; fbarcacianu@yahoo.com; apostolliv@yahoo.com

${ }^{2}$ General Conf Grup, București, Romania, razvan_alin_cb@yahoo.com;
} 
Although it was based on a high number of observations coming from Germany, one can observe their high frequency close to the Pyrenees, The Alpes and in Romania. Another study (Punge et al, 2014) identified every single hail band with hailstones falls on the whole Europe's territory. In order to detect severe convections and hail potential, a cloud-top brightness temperature was used. Therefore, for the 2004-2011 years, the spread and the spatial distribution of the severe convective storms was calculated. Along with the on-site observations of the hail size coming from the European Severe Weather Database (Dotzek et al, 2009), the cloud-top brightness temperature was usedin order to obtain a cartographic imitation of the hail's probability formation on Europe's territory. Moreover, a high density of such events can be seen close to The Pyrenees, The Alpes and in Romania.

Počakal et al, (2009) made an analysis ofthe influence of orography over the hailstorms frequency in Croatia, using data gathered from the continental part of the country between 1981-2006. According to the authors, the highest hail frequency is located in the hilly region of the western part of the country, while in the East, where low altitude is more common, we therefore find lower values. According to Simenov's research (Simeonov \& Georgiev, 2003), Bulgaria is exposed to a high number of hail days which causes damage in agriculture (between 54 and 99 days with hail damage on agriculture parcels spanning from 25 to $30 \mathrm{~km}^{2}$ for 70 years). As for Serbia, according to Ćurić \& Janc (2012), the mean highest number of hail days per year $(2,4)$ is located in the western hills of the country, close to the Morava Valley, data confirmed by a reporting network of 235 observation points. In the Republic of Moldova, in an article about the efficiency of hail suppression (Potapov et al, 2007), it is stated the fact that the greatest number of hailstorms is recorded in the north and the higher lands of the central part of the country. Another study for Republic of Moldova (Cazac et al, 2017) shows that severe hail and an associated highimpactweather phenomena cause considerable damage mainly towards the environment, as well as to the agriculture, buildings, transport and infrastructure, yielding $50 \%$ of the total damage which is comparable to the drought impact.

Studies related to the hail subject, which included the Romanian territory, started to come into sight in the latter half of the last century (Bogdan, 1999; Iliescu et al, 1983; Erhan, 1986). The territorial distribution of hailstones is largely influenced by local climate conditions. Local conditions are also greatly influenced by the Carpathian chain that causes diurnal temperature differences, higher on the eastern side (Apostol \& Sfîcă 2013) and severe rainfall amounts (Croitoru et al, 2015).

Using data records from weather stations located all over Romania, in the study Clima României (2008), a map was made which showed the spatial distribution of hail in Romania. According to the authors, in most parts of the country, the mean number of hail days per year is lower than two days. Areas in which the mean number of hail days is greater, over 8 days per year (10,4 in Semenic Mountains, 9,7 in Vladeasa 1800), are located in the mountain perimeter of the western part of the country, where the instability brought by the Mediterranean or even tropical air masses is added to the strong convective physical processes.

For the extra-Carpathian territory, in Moldova,high frequencies were registered in the high western areas (the interfluve between the hydrographic basins of the Siret and Prut rivers and of the Bârlad respectively) then on the west-east strips of the high strings (BourIbăneşti Hills, Copalău-Cozancea Hills, to a small extent the Jijia-Bahlui interfluve, the Iaşi Slope, the Racova Slope-Lohan Hills). High frequencies (1.02-1.09 days) were also found in big urban centers (Apostol \& Machidon 2011, 2011b). 


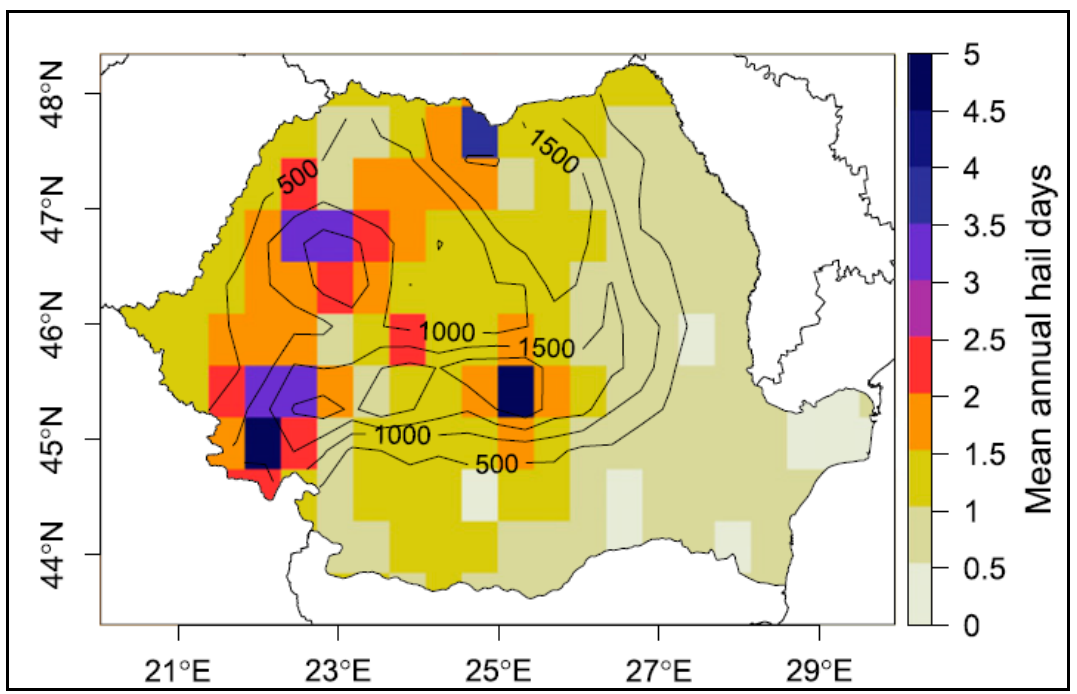

Fig.1 Spatial distribution of the mean hail days per year for the period 1961-2014. The black contour lines show the areas where the altitude is higher than $500 \mathrm{~m}$ (Burcea et al, 2016, p. 4292).

The most recent study in which a hail climatology was performed and published for the Romanian territory (Burcea et al, 2016), a series of data coming from 105 weather stations, between 1961-2014, were used and the following statistics came out as the highest frequency value of hail, of 11,8 days per year, was calculated for North-West, and the lowest value - in the South-Est, near the Black Sea (Fig. 1). The authors also came to the conclusion that the variability for the mean number of hail days from one year was connected to the variability of the low-pressure systems extent, that are initiating above the Atlantic Ocean, which could furthermore generate low-pressure system above the Mediterranean Sea which in turn would transfer humidity in the lower altitude towards the Eastern Europe.

\section{DATA AND METHOD}

Severe weather reports were derived from ESWD for years 2007-2016. The main goal of the ESWD database (Groenemeijer et al, 2004, Groenemeijer et al,2005) is to collect and provide detailed and quality controlled information on severe convective storm events in Europe using a homogeneous data format and web-based, multi-lingual user-interfaces where both the collaborating European national meteorological and hydrological services NMHS and the public can contribute and retrieve observations (Dotzek et al, 2009). The veracity of reports for severe meteorological phenomena in ESWD is verified by radar and satellite imagery. Concerning the country of Romania, there are studies where the on-site observations have been verified. For instance, a severe hail case dating from 24 May 2015 was analysed using data from Doppler WSR-98D Bobohalma (Mures) radar (Somesan \& Makkai 2016). Reports of very strong convective manifestations as tornadoes were made using satellite imagery (Nucuta, 2012).

European Severe Storms Laboratory (ESSL) rates the credibility of the reports on a 4level scale: as received (QC0), plausibility check passed $(\mathrm{QC} 0+)$, there port confirmed 
(QC1), and event fully verified (QC2). In the present study, only reports with the QC1 credibility level were used. The development of social media and an increase in people's interest in severe weather that took place in the recent years significantly increased the number of reports too (often accompanied by a photograph of the event). This database does not include all of the hail reports, but it is the best existing source for the Romanian territory. During 2007-2016 the ESWD received 470 reports tagged with the QC1 credibility level. Processing statistical data takes place after receiving this very detail. First of all, the row of data concerning hail was analysedin order to achieve a temporal and spatial frequency of the phenomena on. In the spatial analysis, we took into account the relief stage in which the phenomenon and the number of inhabitants on the $10 \mathrm{x} 10 \mathrm{~km}$ grid occurred in the year 2015 .

\section{RESULTS AND DISCUSSION}

The density of large hail reports for the Romanian territory is low (50 - 70 reports per $10000 \mathrm{~km}^{2}$ ) compared to Germany, Austria or northern Italy where there are over 200 reports per $10000 \mathrm{~km}^{2}$ (Groenemeijer et al, 2017). The highest density of reports came from north-east, south-east and north-western Romania. Many of these reports were received from the neighbouring places affected by the same hailstorm (Fig 2). In the northeast, there are big occurences of lightnings, with over 60 cases / $100 \mathrm{~km}^{2}$ between 2010-2014 (Sfica et al, 2015) and thus they come in hand with a strong convective activity.

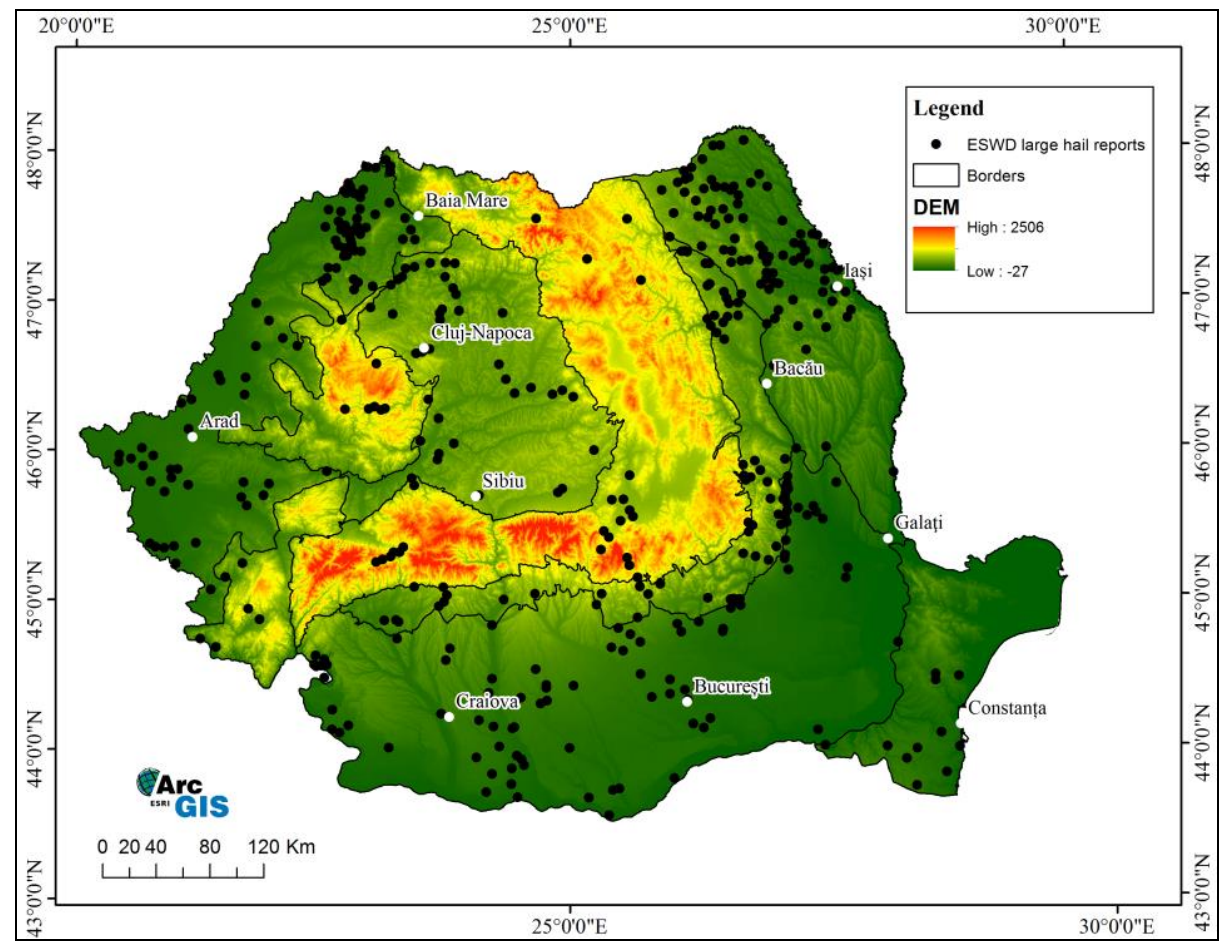

Fig. 2 Spatial distribution of large hail reports with the rate of credibility QC1 for the period 2007-2016. The black contour lines show the major relief divisions. 
Throughout 2007-2016, several supercellular processes have been reported that have affected the northeast and northwest. Other areas, such as the central-eastern part of the Apuseni Mountains and the Transylvanian Depression, which include hail reports, coincide with areas where for the period 2004-2009, the meteorological radar from Bobohalma recorded numerous hailstones with a diameter of over $7 \mathrm{~cm}$ (Maier et al, 2010). Most of the reports are recorded in low plains, at altitudes below $200 \mathrm{~m}$ and the lowest in mountain regions, over $800 \mathrm{~m}$ (Fig 3).

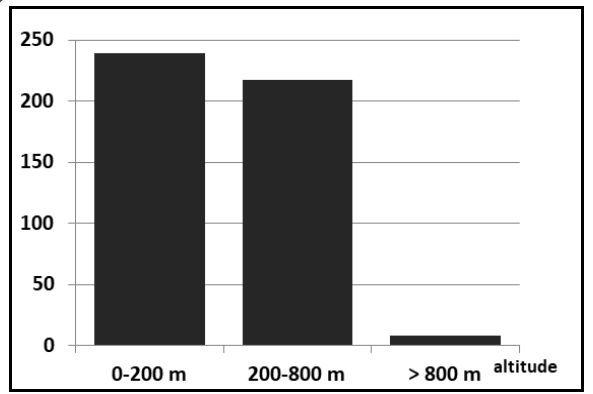

Fig. 3 Number of large hail reports by altitude classes

Data shortage is coming from the most parts of the mountain areas to altitudes above $800 \mathrm{~m}$, can be explained by the low population density and the lack of witnesses who would report events such as hailstorms.

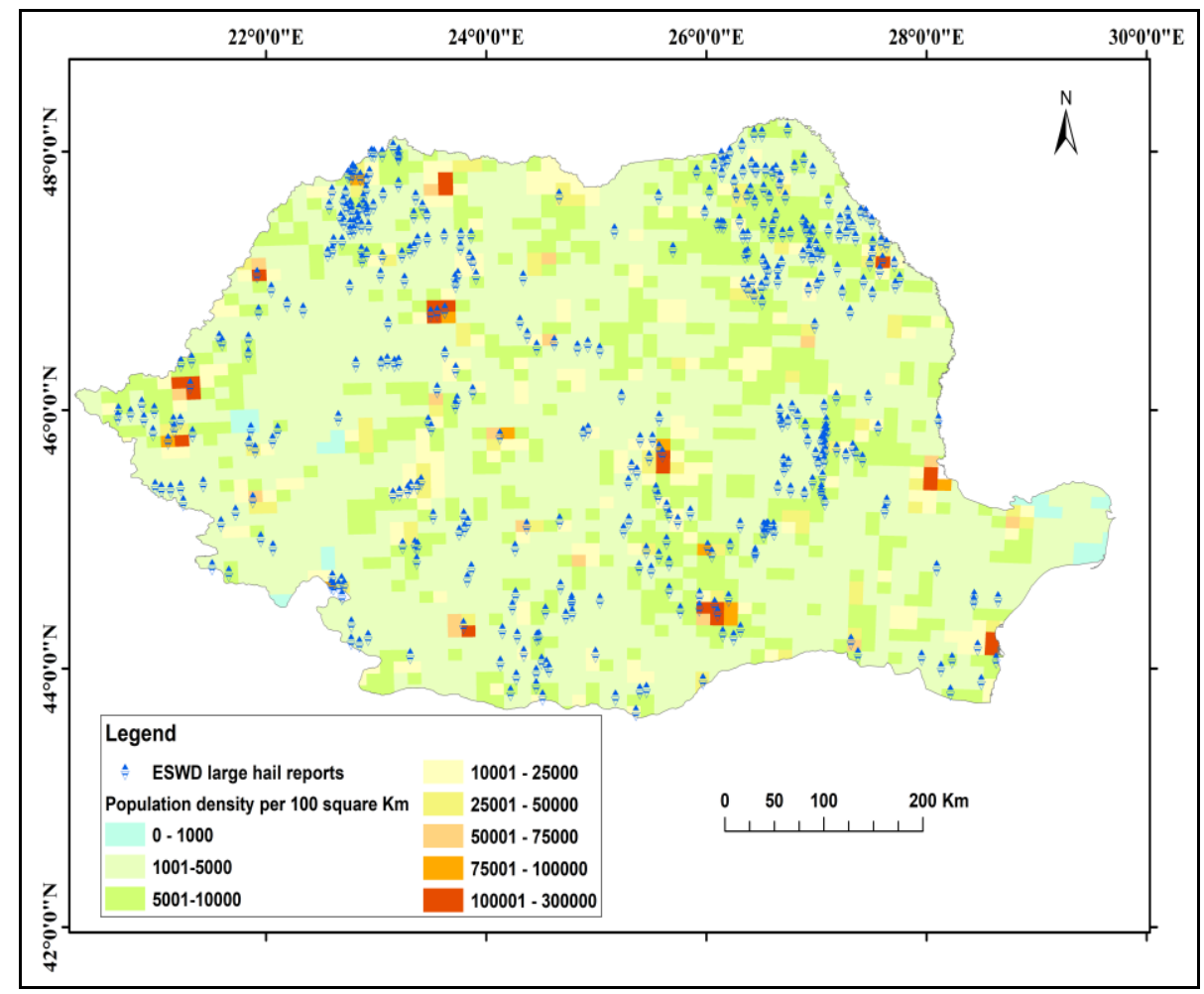

Fig.4 ESWD large hail reports compared with population density 
Regarding the Baragan Plain, Bârlad Plateau and Northern Dobrogea, the number of reports is extremely small. In general, the areas where there are no reports of the phenomenon may very well coincide with those where the population density is below 5,000 places $/ 100 \mathrm{~km}^{2}$. In the same time, the largest hail diameter reports come from more populated areas or near major urban centers (Iasi, Bucharest, Brasov, Cluj-Napoca) (Fig. 4).

There are also areas where the high numbers of reports or occurences do not match with a high population density, such as the Carpathian Curvature area or eastern Oltenia. Most likely, this can be explained by the atmospheric circulation and the local climatic conditions. The Carpathian Curvature area is most affected by the instability caused by the Pontic Basin (Ionițe \& Sfîcă, 2016) in the warm season. Oltenia and the entire southwestern part of the country are the most affected areas by the Mediterranean cyclone trails which come with a lot of warm and humid air that can often clash in contrast with the preexisting cold air (Garaba \& Sfîcă, 2015).

The number of reports over the ten-year period has been highly influenced by the progress of ESWD network. In the first year, 2007, a very small number of events were reported on Romania's territory. During 2008-2010 there were recorded between 40 and 50 reports per year. The year 2011 featured a small number of reports (Fig.5), which could mostly be a consequence of the climate particularities of that very year.

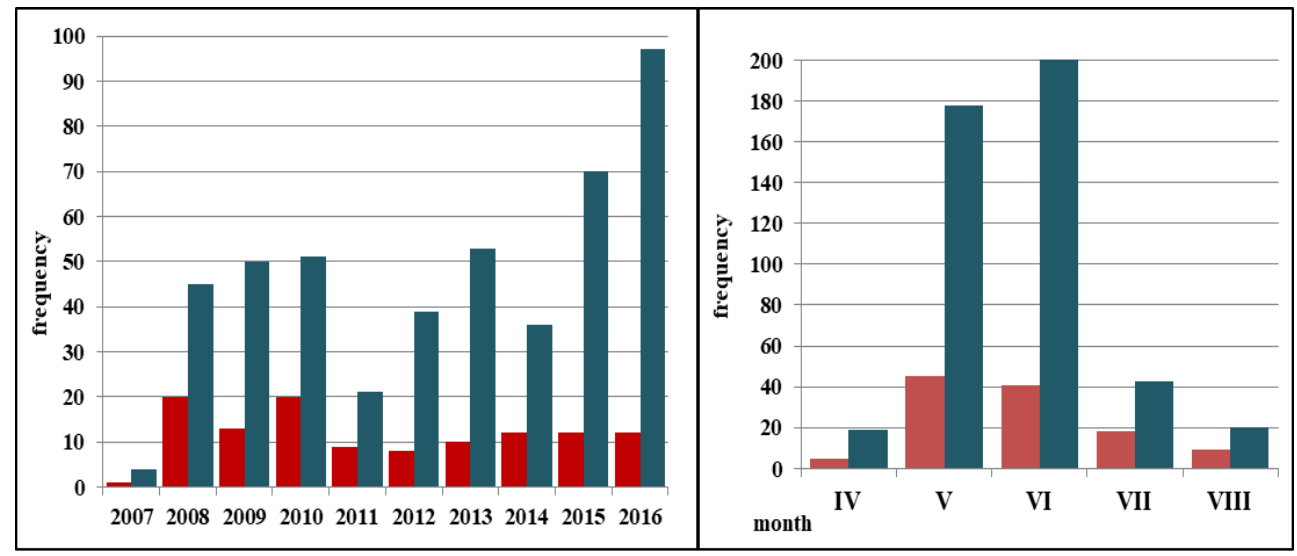

Fig. 5 Annual frequency of hail days (red bar) and reports (blue bar) - left. Monthly frequency of hail days (red bar) and reports (blue bar) - right.

The actual number of hail days shows a trend evolution which does not go in hand with the number of reports. A greater number of hail days can be noted in 2008, 2009 and 2010, a decline in 2011 and 2012, and during 2013-2016, 10 to 12 of hail days per year were actually recorded. The high numbers of reports related to the low numbers of hail days reports of the last lapse could be a cause of the heighten outcome for the convective physical processes and because of a better broadcast coverage of this meteorological phenomenon.

The monthly multiannual distribution of reports number shows two peaks in May and in June (Fig. 5). June is the month with fewer hail days than May, but with a greater number of reports. This scenario is due to the climate differences between the two dates. The cumulus clouds systems in May are more frequent, a part of this month being overlapped by the highest rainfall in Romania (Clima României, 2008). 
Furthermore, the first part of the convective season is characterised by a lower altitude of the $0^{\circ} \mathrm{C}$ isotherm (Istrate et al., 2016) thus, greater chances for hailstorms to occur. The hourly distribution of the reported hail falls meets one peak between 13:00 and 15:00 hours and other two between 18:00-19:00 and 20:00-21:00, respectively (Fig. 6).

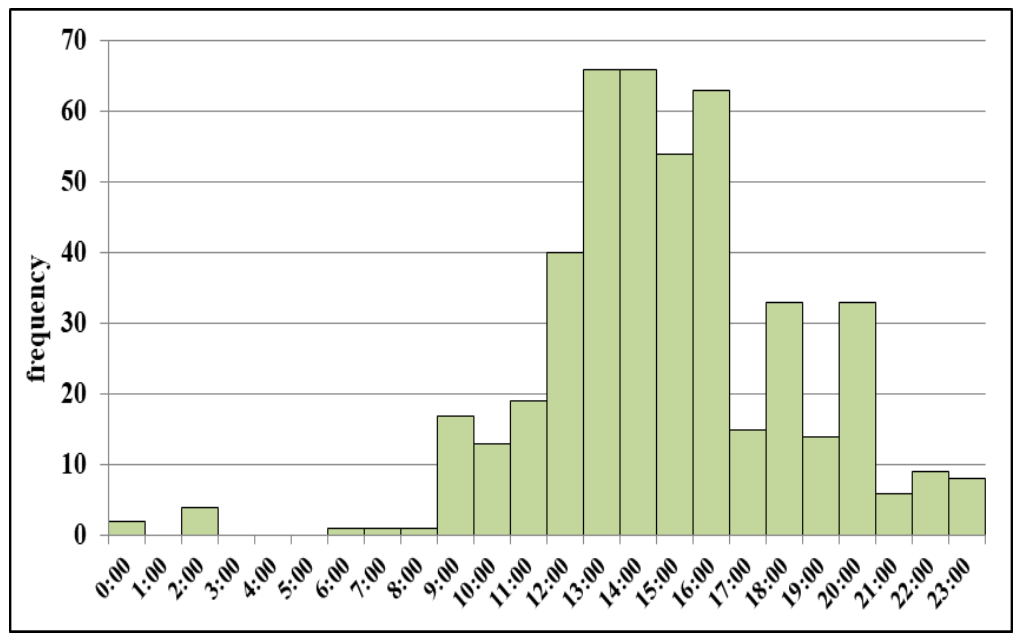

Fig. 6 Hourly distribution of hail falls reported

\section{CONCLUSIONS}

For the 2007-2016 period, 470 large hail events with QC1 credibility level were reported. The spatial distribution of recorded hail falls is influenced by the population density in each region and by the number of people interested in reporting severe atmospheric phenomena. However, areas with high reporting densities are observed, such as the north-eastern and the north-western parts of the country or the Carpathian Curvature area.

The annual evolution of the reported number of hail falls is fluctuating possibly influenced to a large extent by the climatic characteristics of each year. Regarding the monthly multiannual evolution, most reports were in May and June.

Using the ESWD for large hail is very useful for studying this phenomenon. The increasing number of reports helps improve the climatology of hail and establish trends for the past decade. Also, on-site observations improve the hail forecast accuracy, which is fundamental for the National Hail Suppression System, that was recently implemented in Romania ( Istrate et al. 2016b).

\section{ACKNOWLEDGMENT}

Many Thanks to the European Severe Storms Laboratory (ESSL) team for providing data on large hail reporting on the territory of Romania between the years 2007-2016, available in the European Severe Weather Database (ESWD). 


\section{R E F E R E N C E S}

Administrația Națională de Meteorologie (2008), Clima României. București, Romania, Edit. Academiei Române.

Apostol, L., \& Machidon, O. (2011). Considerations on the hail regime in Moldavia between the Siret and Prut rivers. Aerul si Apa. Componente ale Mediului, 2, 45-52.

Apostol, L. \& Machidon, O. M. (2011b), 'The hail phenomenon in the Bârlad Drainage Basin - some aspects regarding genesis and diurnal frequency', Present Environment and Sustainable Development, 5(2), 209-219.

Apostol, L., \& Sfica, L. (2013). Thermal differentiations induced by the Carpathian mountains on the Romanian territory. Carpathian Journal of Earth and Environmental Sciences, 8(2), 215-221.

Bogdan, O., \& Niculescu, E. (1999). Riscurile climatice din România. Academia Română. Institutul de Geografie.

Burcea, S., Cică, R., \& Bojariu, R. (2016) Hail Climatology and Trends in Romania: 19612014. Monthly Weather Review, 144(11), 4289-4299.

Cazac, V., Daradur, M., Leah, T., \& Pandey, R. P. (2017) Effects of hail suppression operational programs on hail frequency and environment in Moldova. Present Environment and Sustainable Development, 11(1), 141-150.

Croitoru, A. E., Piticar, A., \& Burada, D. C. (2016) Changes in precipitation extremes in Romania. Quaternary International, 415, 325-335.

Curić, M., \& Janc, D. (2016) Hail climatology in Serbia. International Journal of Climatology, 36(9), 3270-3279.

Dotzek, N., Groenemeijer, P., Feuerstein, B., \& Holzer, A. M. (2009) Overview of ESSL's severe convective storms research using the European Severe Weather Database ESWD. Atmospheric research, 93(1), 575-586.

Erhan, E. (1986). Fenomenul de grindină în Podişul Moldovei, Analele Știiţifice ale Universităţii Al. I. Cuza, Iaşi, serie nouă, secț. II, b, Geografie-Geologie, tomul XXXII

Garaba, L., \& Sfîcă L. (2015) Climatic Features of the Romania Terrritory Geterated by the Action of the Mediterranean Cyclones. Lucrările Seminarului Geografic „Dimitrie Cantemir", 39 (1), $11-24$.

Groenemeijer, P., Dotzek, N., Stel, F., Brooks, H., Doswell, C., Elsom, D., \& Salek, M. (2004) ESWD-A standardized, flexible data format for severe weather reports. In Preprints, 3rd European Conf. on Severe Storms, Leon, Spain, 2-12

Groenemeijer, P., Dotzek, N., Stel, F., \& Giaiotti, D. (2005) First results of the European Severe Weather Database ESWD. Preprints. In 5th Ann. Meeting of the European Meteor. Soc., Utrecht, Netherlads, 12-16.

Groenemeijer, P., Púčik, T., Holzer, A. M., Antonescu, B., Riemann-Campe, K., Schultz, D. M., \& Koppert, H. J. (2017) Severe convective storms in Europe: Ten years of research at the European Severe Storms Laboratory. Bulletin of the American Meteorological Society.[Online], Aviable from: http://journals.ametsoc.org/doi/pdf/10.1175/BAMS-D-16-0067.1, [Accessed 20th July 2017]

Hand, W. H., \& Cappelluti, G. (2011) A global hail climatology using the UK Met Office convection diagnosis procedure (CDP) and model analyses. Meteorological Applications, 18(4), 446-458.

Iliescu M. C., Popa C., (1983), Particularități ale distribuției grindinei pe teritoriul R. S. România, Studii și cercetări, Meteorologie, I.N.M.H., București

Ionițe, I., \& Sfîcă, L. (2016) The Black Sea As Contributor To the Precipitation Amount on Moldova Region. In Physical Geography; Cartography; Geographic Information Systems \& Spatial Planing :Proceedings of the 2nd International Scientific Conference Geobalcanica 2016, Ohrid, Republic of Macedonia, 51-58.

Istrate, V, Apostol, L., Bărcăcianu Florentina, Iordache, I. \& Sfícă, L. (2016) Precursor Weather Conditions for Hail-Event Forecasting in the Moldavia, Air and Water-Components of the Environment, 8, 203-209. 
Istrate, V., Axinte, A. D., Apostol, L., \& Machidon, O. M. (2016b) The efficacity of hail supression in Iasi county (Romania) case study 09 july 2015. In Air Pollution and Climate Change: Proceedings of the 16th International Multidisciplinary Scientific GeoConference SGEM 2016, Albena, Bulgaria, 631-638.

Maier, N., Lacatus, D., \& Rus, T. (2010) Hail in the area covered distribution of WSR-98D radar from Bobohalma. Air and Water - Components of the Environment, 2, 404-411.

Nucuță, C. (2012). The analysis of the enhanced-v structures atop tornadic storms across Romania. Geographia Technica. [Online]. 15(1), 72-82, Aviable from: http://technicalgeography.org/pdf/1_2012/08_calin_nucuta_the_analysis_of_the_enhanced_v.pdf , [Accessed 25th July 2017].

Počakal, D., Večenaj, Ž., \& Štalec, J. (2009) Hail characteristics of different regions in continental part of Croatia based on influence of orography. Atmospheric Research, 93(1), 516-525.

Potapov, E. I., Burundukov, G. S., Garaba, I. A., \& Petrov, V. I. (2007). Hail modification in the Republic of Moldova. Russian Meteorology and Hydrology, 32(6), 360-365.

Punge, H. J., \& Kunz, M. (2016). Hail observations and hailstorm characteristics in Europe: A review. Atmospheric Research, 176, 159-184.

Punge, H. J., Bedka, K. M., Kunz, M., \& Werner, A. (2014) A new physically based stochastic event catalog for hail in Europe. Natural hazards, 73(3), 1625-1645.

Sfîcă, L., Istrate, V., Lesenciuc, L. D., \& Necula, M. F. (2015) Instability indices as predictors of atmospheric lightning-Moldova region study case. In Hidrology and wather resources, Proceedings of the 15th International Multidisciplinary Scientific GeoConference SGEM 2015, Albena, Bulgaria, 387-394.

Simeonov, P., \& Georgiev, C. G. (2003) Severe wind/hail storms over Bulgaria in 1999-2001 period: synoptic-and meso-scale factors for generation. Atmospheric Research, 67-68, 629-643.

Someșan, R. A., \& Makkai, G. (2016) Medium and large hail in Transylvania, locality of Band, 24th May 2015. Geographia Technica, 11(1), 67-83.

*** Archive of synoptic maps. [Online] Aviable from: http://www1.wetter3.de [Accessed between 5 June and 25 July 2017].

*** National Institute of Statistic, TEMPO online time series. [Online] Aviable from: http://statistici.insse.ro [Accessed between 15 June and 17 July 2017]. 